better this yen them $d$ eve hove for wi all go tor chureli thrice a day on Sunday No drinking for eight month. Id e is dinge t well and teacher 13 yo boy j Io say and tell th truth he only broth tow yo r have that

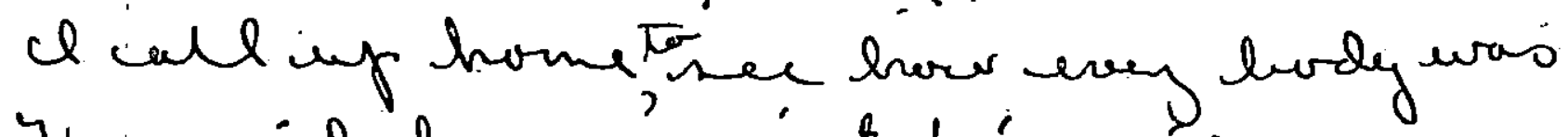
It said he was fie t fine jolly wo ever I do knew that yer mid you wert to biel.

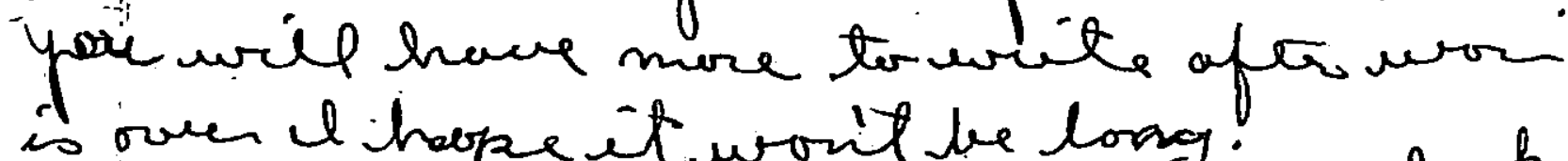
is oven el hap pe it wo it be long. your pretor cation grovel of you. you look bopper than yer eve base been

Mary came for for day is but never died come de re me, But who care $l$ dort.

Lay" I let Low read the letter got from you. ad but th s insurance. She sail shy mot get your lett \& gees. that what she mean

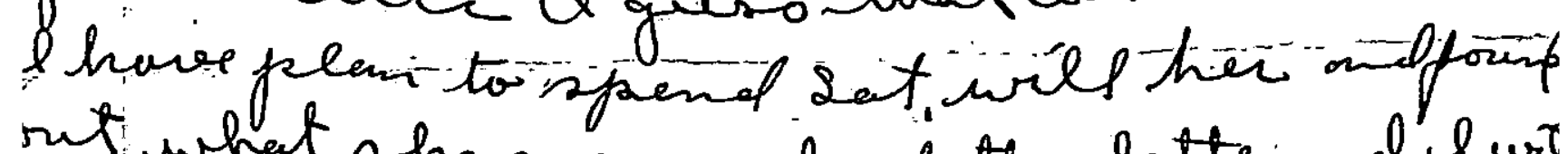
nit what she mean about the letter and levi rite late on. and tell you.

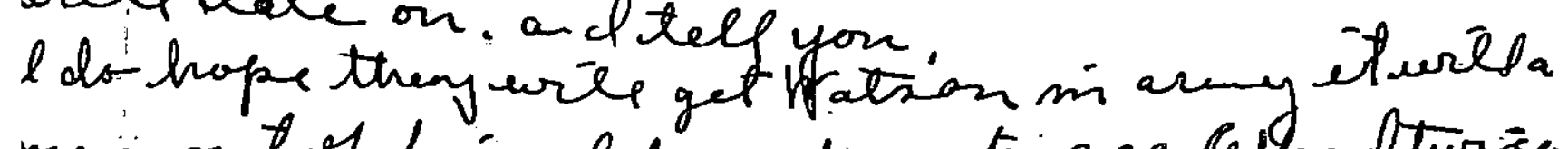
main out of hin. I have been to see Reifredtrice but he eves off. It e start two chit eden manley. it tile oo he doing alright so for.

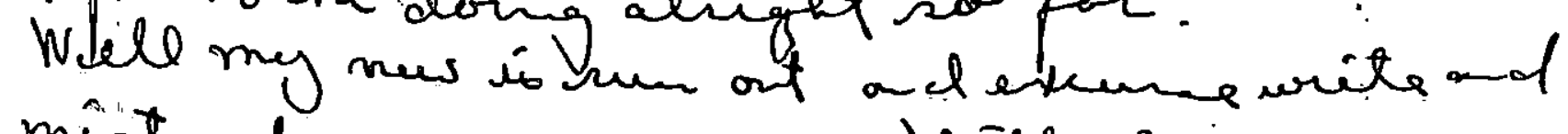
mistrals The world urlepray for
peace sep ty. With lave

Pone 


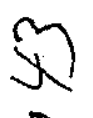

Bangisin,

333 Oricinod Aur. Blaskenille, Temi. Sypt., 1942

d who not liven mas inderal a plesme. an not sufpised at you wing in the

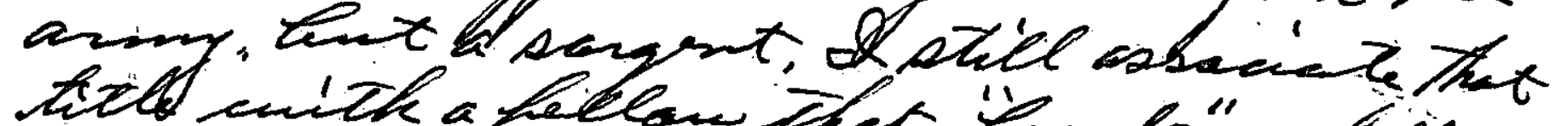

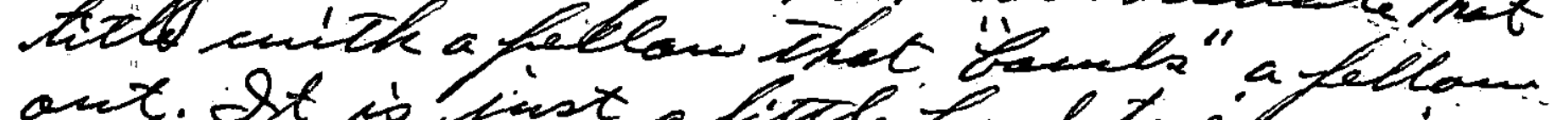

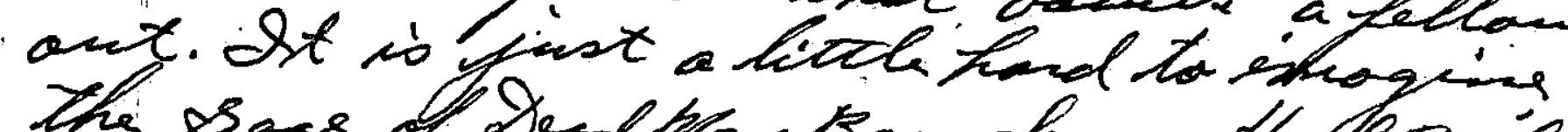

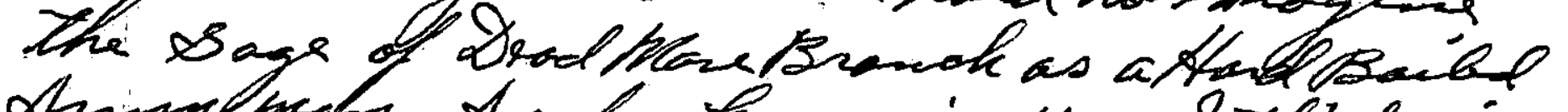
Aring matr. As for terning you dhink it

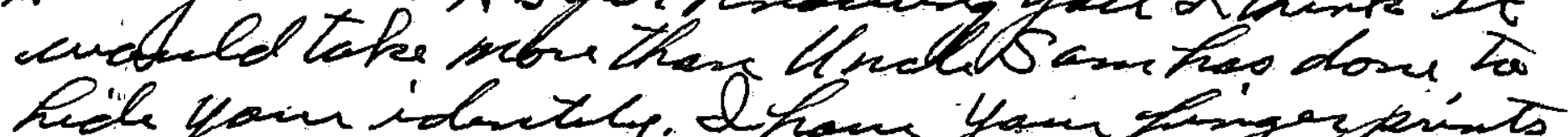
hile you id wely, dhom Yain hing pin ts

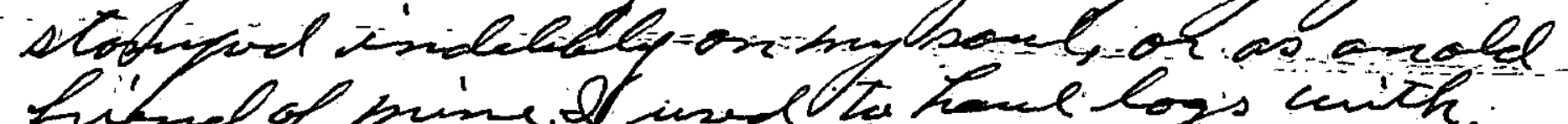

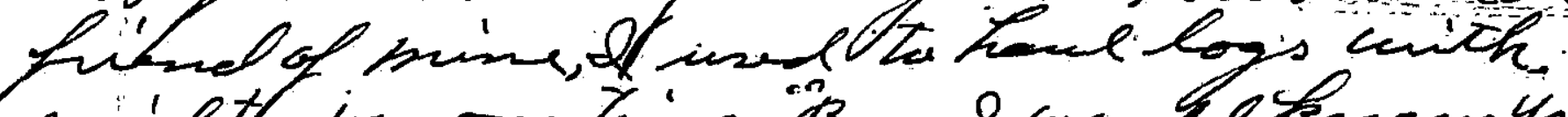

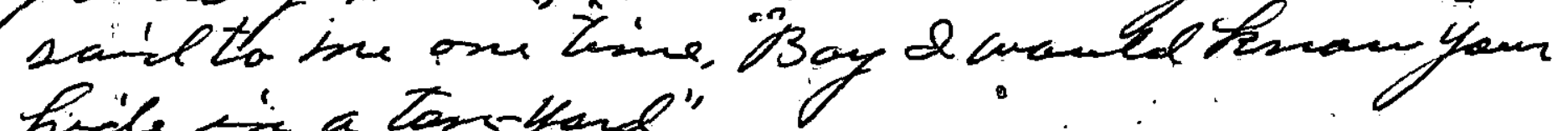
hide is a taryyand".

The two with yai spoke of in Olaikanich.

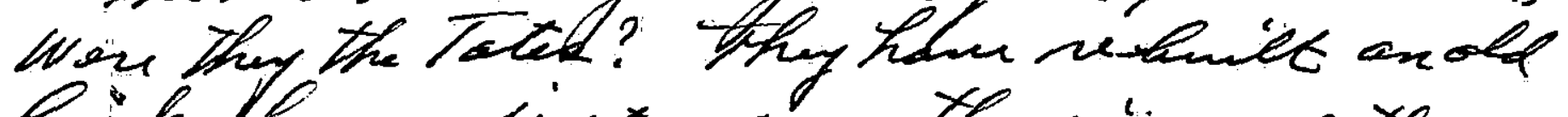
hich thanse fist a cravs the mine at the red

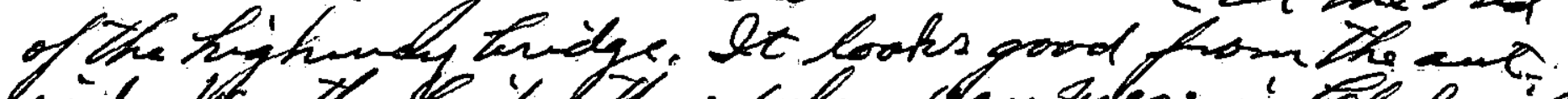

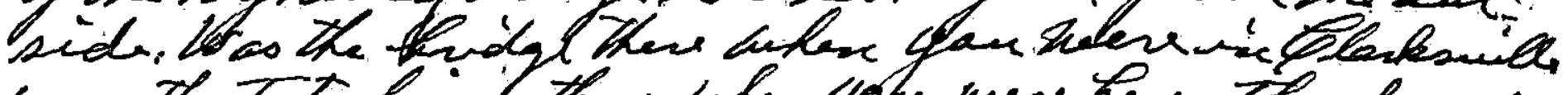

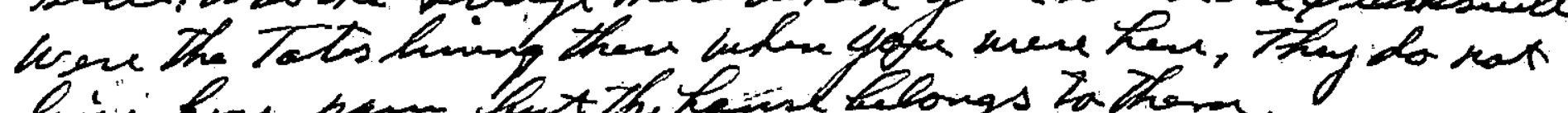

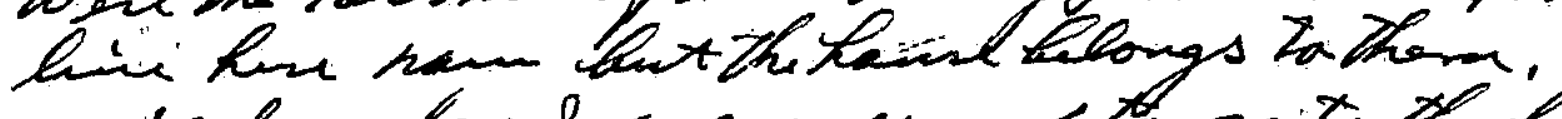

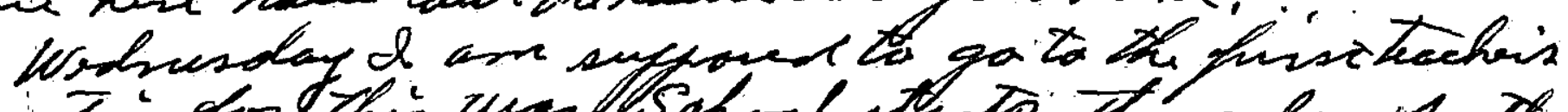
muting for this year schol stusts thins-lay thothe $q$ moxthe grimble if Unch sam dainitg te me, with lest wishes dom.

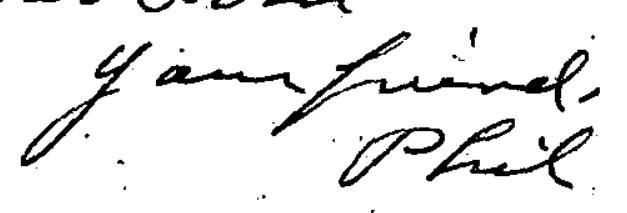


151 Fast 2lst street,

New York, N. Y.

September 8, 1942

\section{Jim! Jim!}

To think I missed you! I can't begin to tell you how it - hurt to come from two days in the country (my first time outside of $\mathbb{N e w}$ York since Yaddo) and find the notice. At times I can't believe it, then the realization comes that it is one of those combinations of fate that'serves to keep you from the thing for which youemost wished.

The message caite after I had left for Long Island on Saturday - probably two hours afterwards. I was in the country where there was no telephone and, as there was no one in my houjse, there was no one even tootry to forward word to me. "To come in and find the notice and to hope against hope that still I could contact you was a hard thing and I grieved.: I rushed to a telephone and called the Information Booth, the Martinique, (hopeling by some chance you might have been there) and the Western Union again - but no word. Was eảger for word from you in this'morning's mail so that this letter could be sent in a direct line instead of by = the roundabout way through Texas. Yet, here it goes, to tell you how bitteriy sorry I am that I could not see you,

And now where are you, Jim? I can only guess. I'm defeated in not seeing you - and there's so little can be done about it. Even ten minutes might have sufficed. But no - I had to be away. I'Il, writte you of the week-end later. It was rich and healthrul, yet to me it's turned out to be 'yust a time that has kept me from seeing you.

Write soon, Jim. "May you safely cross.

$$
\text { My love to you, }
$$




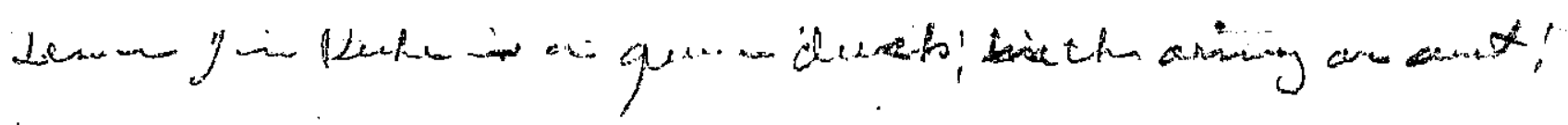

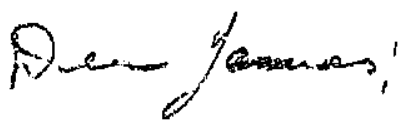

mandiong night

f ped Th, 142?

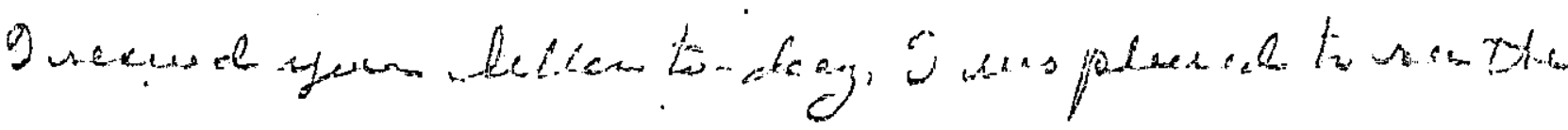

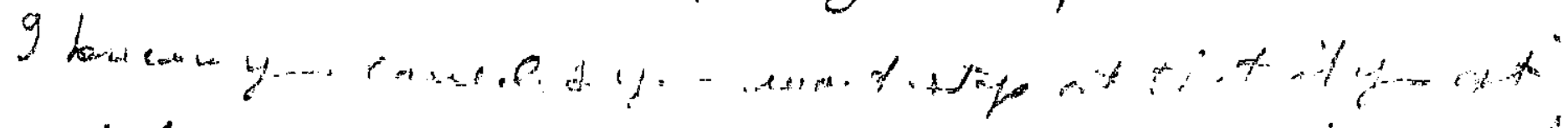

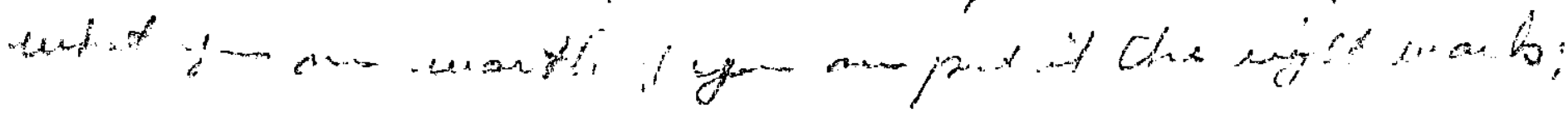

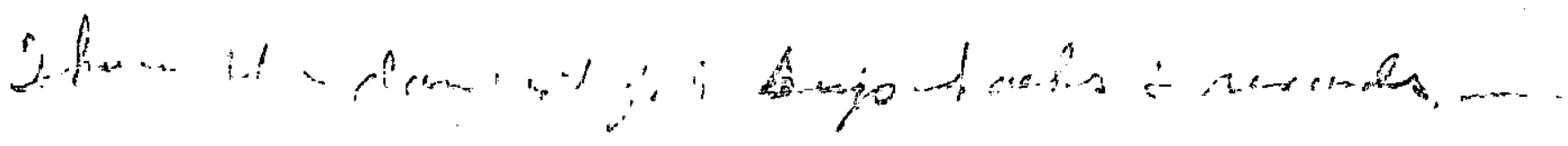

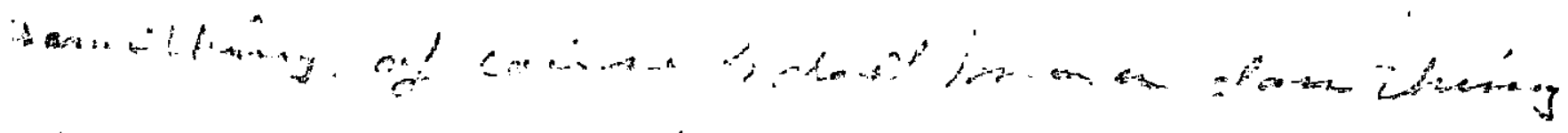

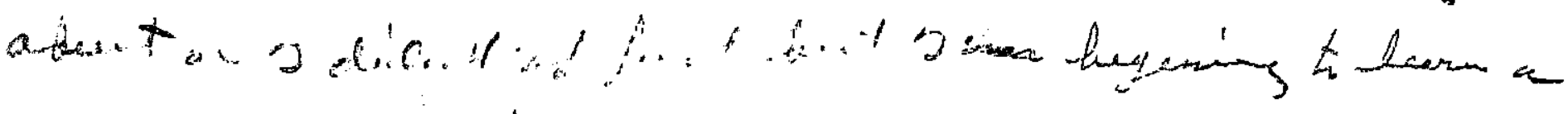
letter nawr I fape,'

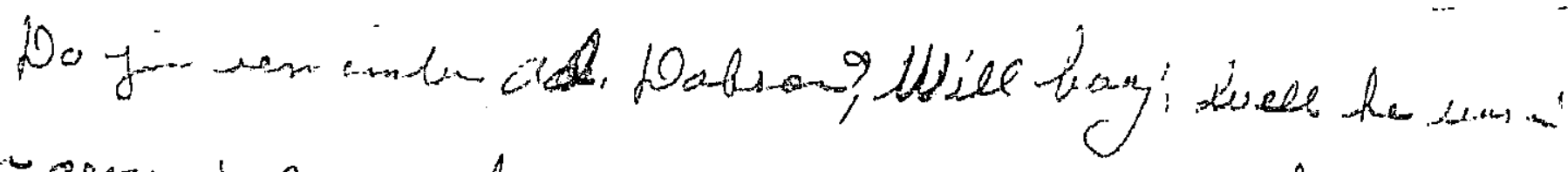

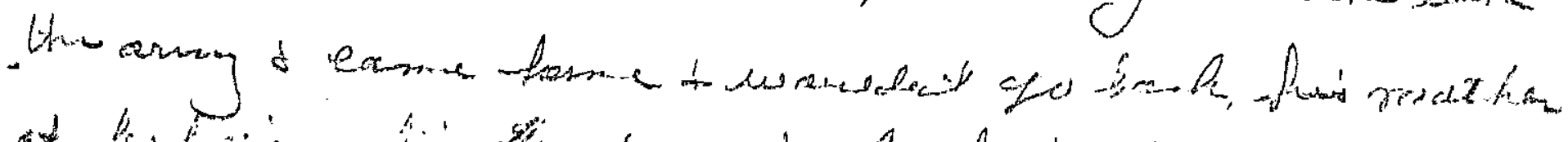

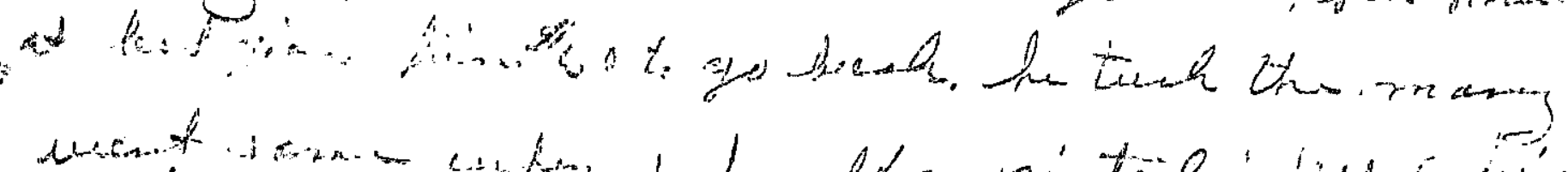

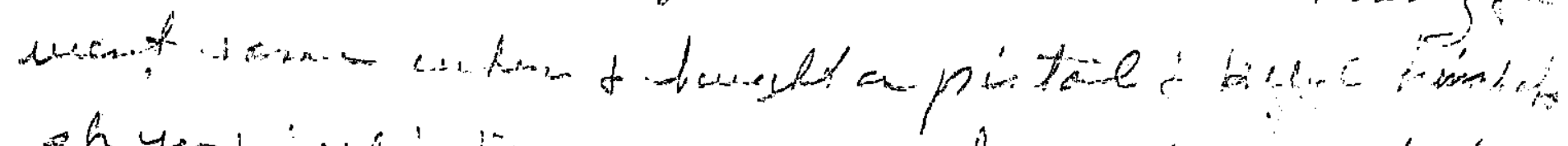

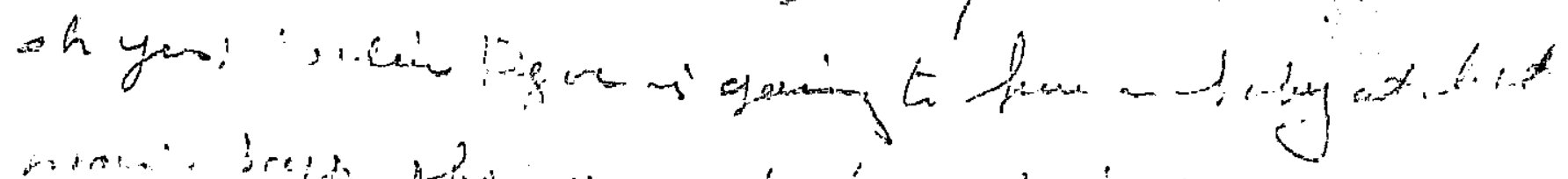

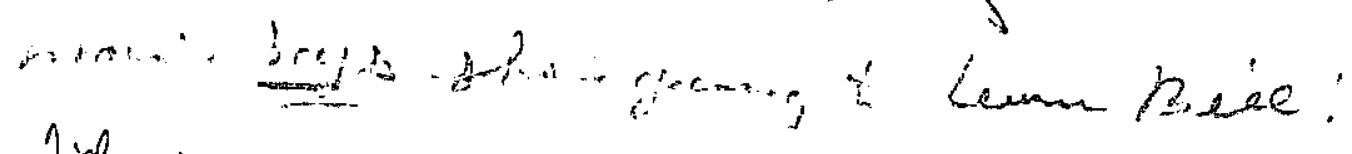

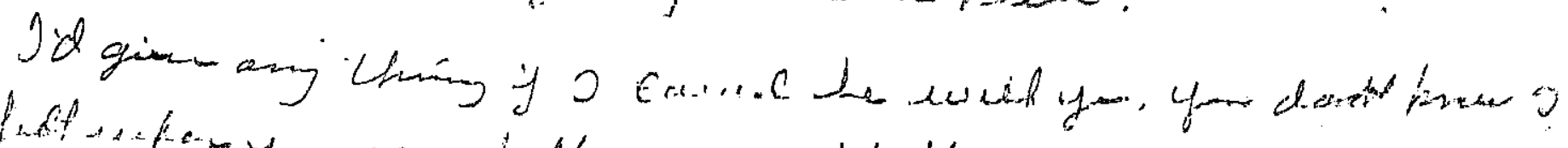

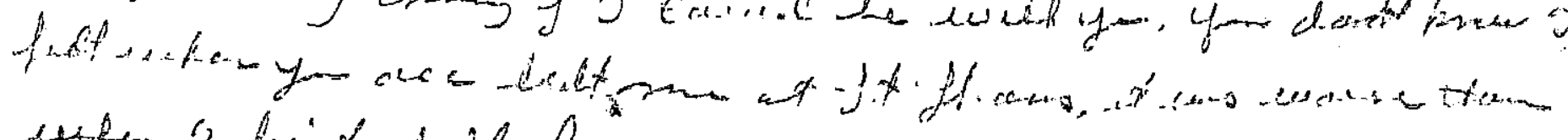

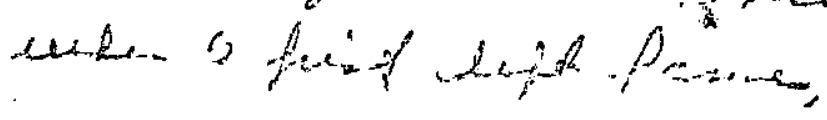

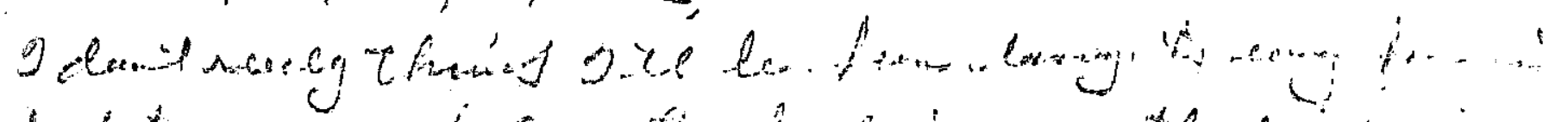

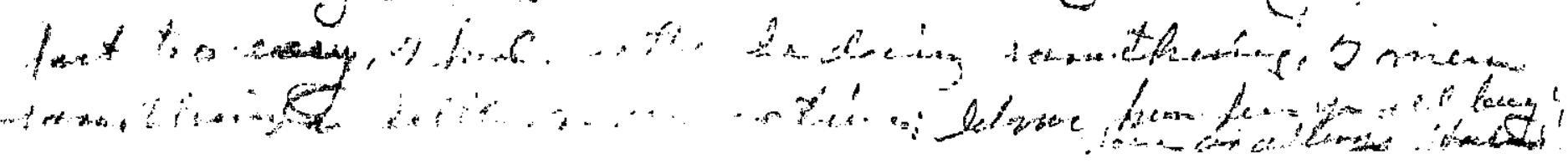







Bills Gion

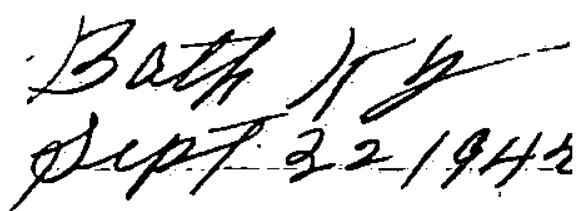

Ifij leaiels us all zull as usuab a are Going to school cuer doy liph wery mell propting

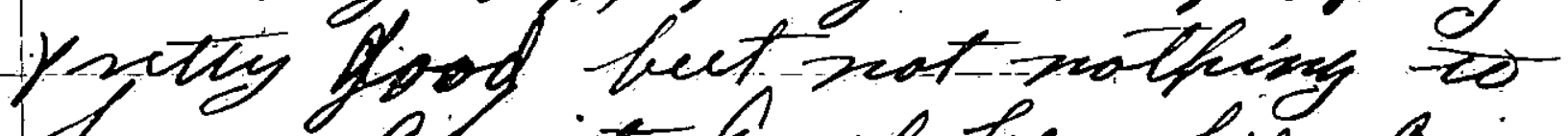
far ag abit Euel hos fien goref leversinef first of guly, he is at parthrmanth 2 a vurfering in 12 deferese factory inaping ofrat liph 25 a pooneth says fur likes $a$ few day to stay a weep.

If is gitteng cald fiei now got to pup a fin the flown. is all afout spedded teter floom

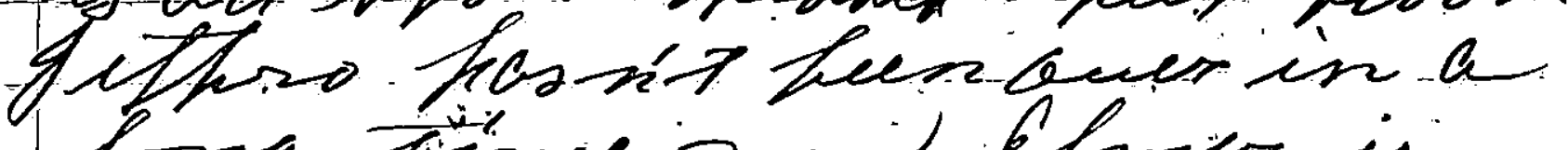
long incs wail Elmave is in litts nock futa glifin firs he says. Dul kad a teles. iom por she wiv as foting it acutul lad fecoust the subs out of tawn. anit is gaing to shod cuer day and mopin \& 1 Guess a fow Close is

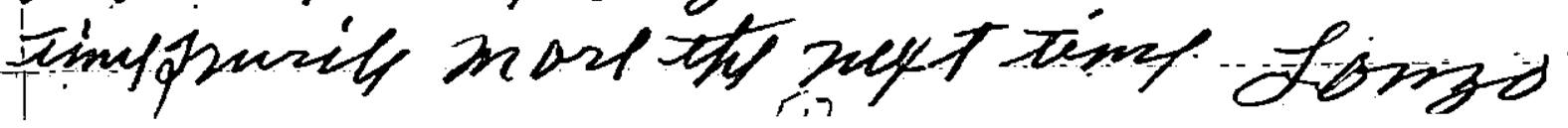


fear it rejom

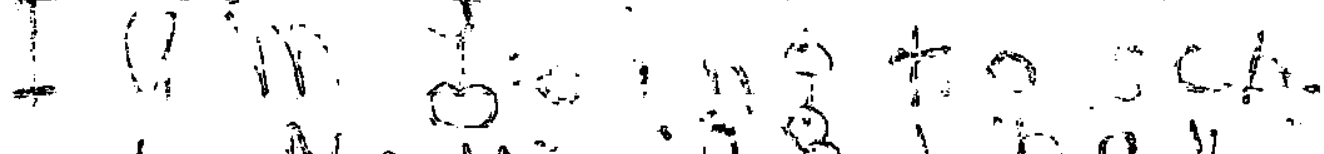

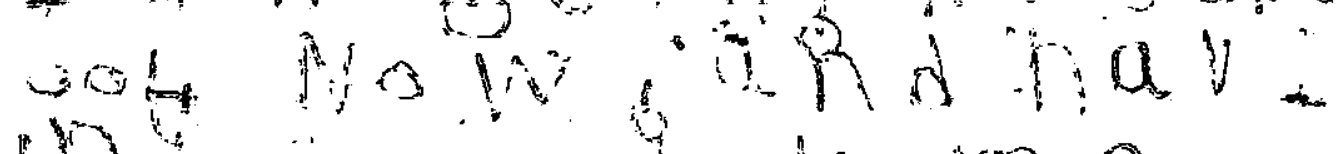
ne 1 t t $n$ e. Love.

* sespaver 
tweaght $1.2 \mathrm{lt}$.

Qearest fameo.

Sadsden ala $\operatorname{sep} 22,1942$

Im ansures to yoir beter we nec= earred also the posf casal thy were enterestring douglas suie engongetwing

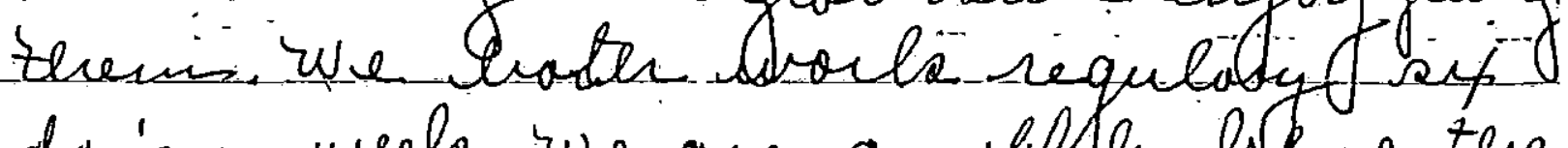

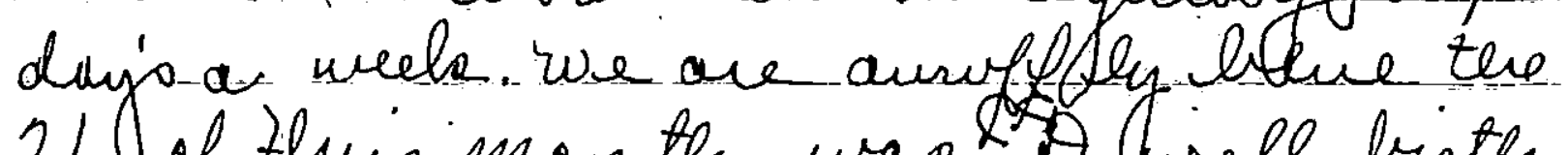
21. of thia month was $O$ hirell birth doulie would hive bees eighteen. - Lerp 2 le of th ey le would he turnty and Aougla d wonto to join yp with the Anug becaure-2le boy aie gane.

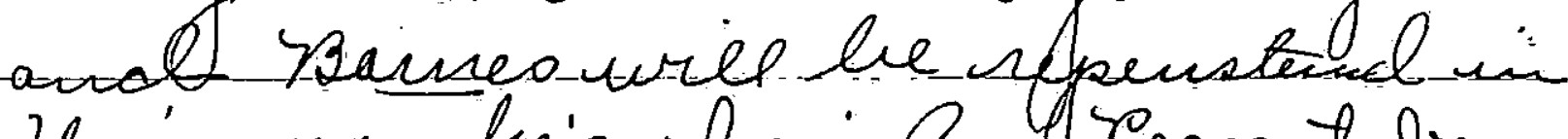
- Livo war hio a raial. Preanut boy prienal is in ter army of: L Mrodess

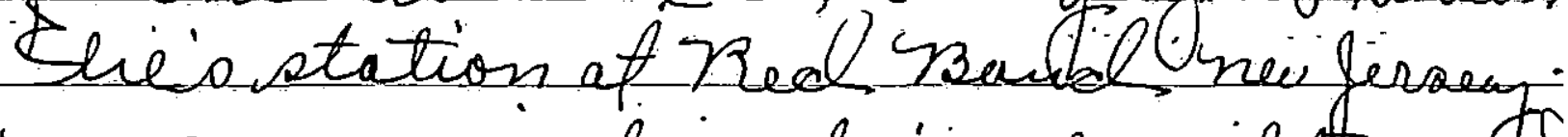
we sure miso him heis only eighterr of he volotineal ifames Loif and deles are commin soon. W e doif erves see mary ard Comer witer sut we go rue thende and carry teum to get growno each saf after nor my S. S. codsomet here with ime friday seming we sure in joyeal it mus colo thativieo next door baly Sundey of ter nover 
it wire only three dayjo old farmes i hupapon too go out to see how they were the baby were lying on a bese to ito selfourdecel uy to see howit was aledping inotical it was harring conrulineng \& dialint say anythis.

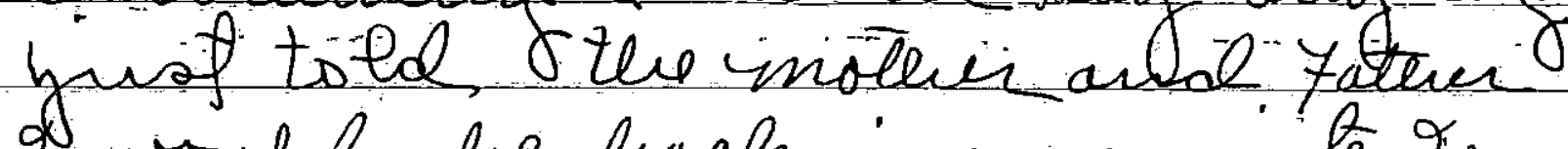

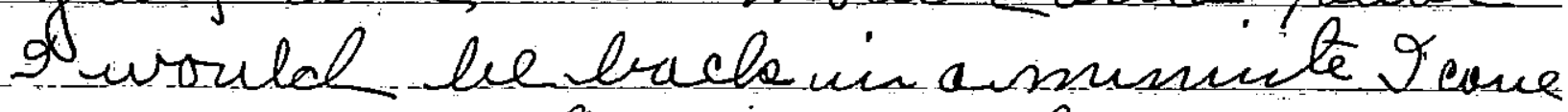
home called oys Bu af once their

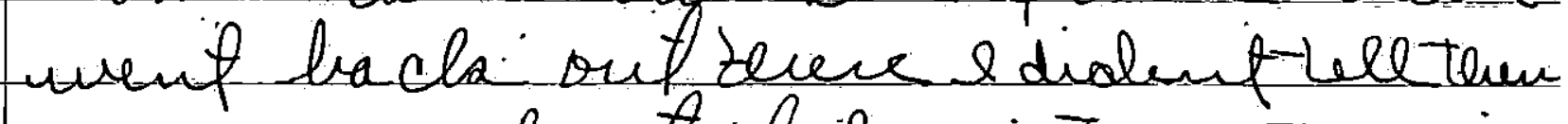
ariz sem abuatif So in TwentyminYie r was ouf butil arlo temip I coudal talap the baby ujo thuy zolal me yes so when saislal the haby ujo to my hesp thichtere

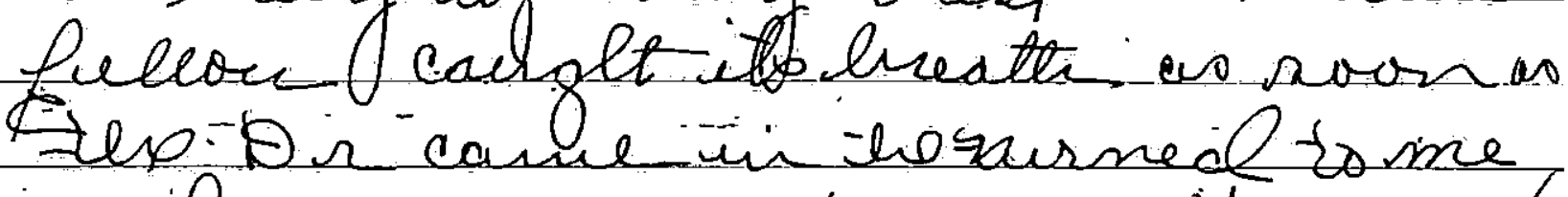
and sajo mar sames I'msogead you caled me when you did far muy he bre has a chahce lwab so

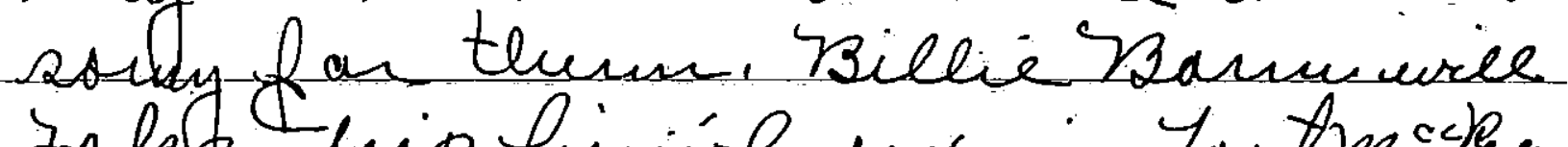

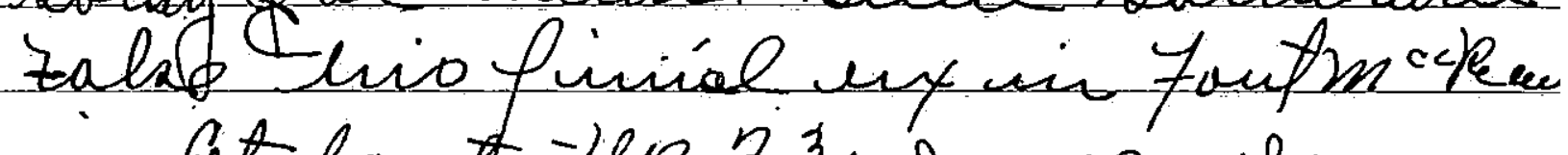
in bet lante- ies 23, fames when you get hack home again bull disude my cannedivegetales aid futio with yor Qive really don terio sat̄mer. 
edonf enu hun from home im Buch Qneal gottion silled by a train a virels ago one of ow neigherrom. il gum: yon hear o about cllove foume burning doum almost l' sent her sesveral phe whe are going to starting paintin

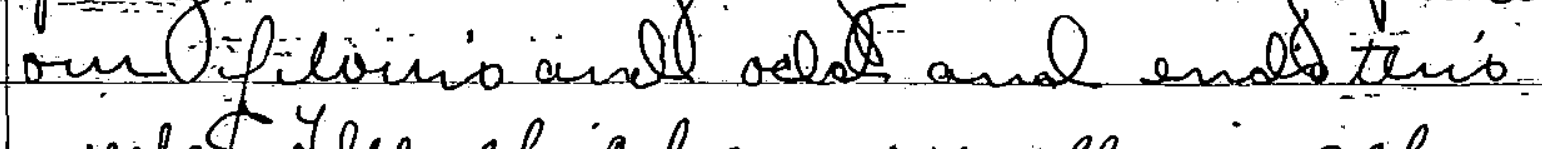
weels The chiden are all nin school seantis manages of she himmighan zort of coarse after Rchave and Sat:

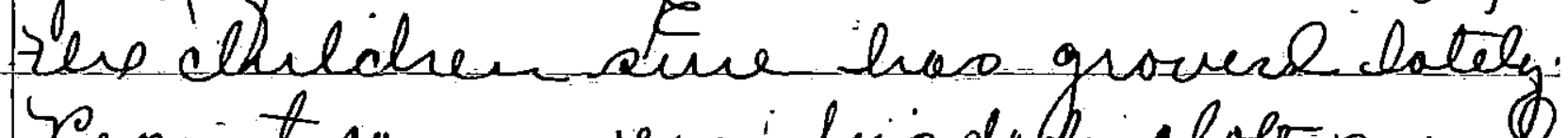
Peonit can wrear hiv dubly clobtex and

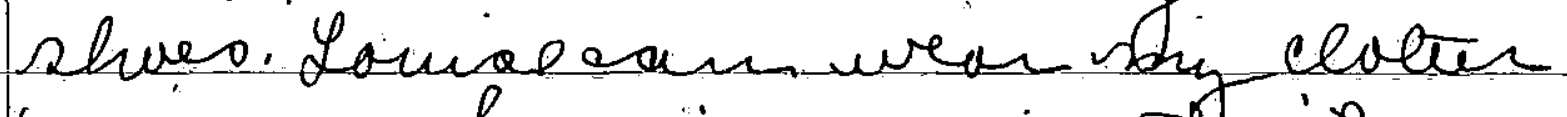
sanbaras lue is growife rthait uy. fames pelease ubite ofton as onglox

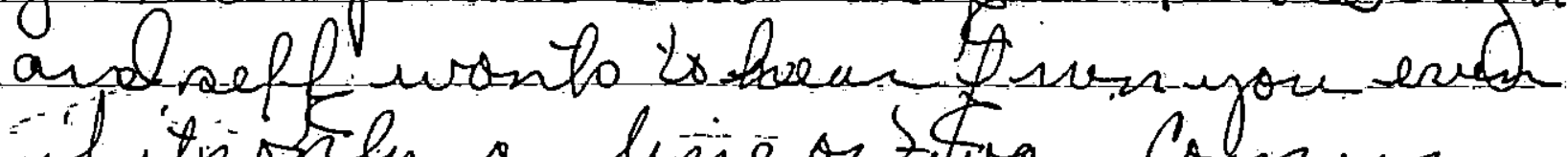
ifitionly a line or two. Conun addresolio, 918 saruce St an sony hamig real coldt nightional hetio dojo, wate soon loto of Lave Jamisterefater away iny loves are themore 9 longed zoed therim bit imay gol heeje you weel analotrong and Guideyom eabh alq and hin you back saffly back to ur agou sid 


\section{GUY LOOMIS}

P. O. BOX 98

BROOKLYN, N. Y.
Sept. 29th-42

A long way for a letter to go to go down to miami and then back to N.J.

in order to reach you.Your postal came postmarked tirenton N.J.twoweeks ago and am wondering if. they have started you off to "furrin parts" Drop the enclosed card if you get this letting me know you are $0 . K$. Kate Loomis had to undergo an operation around her throat but is $0 . K$. and will soon be out of the hospital. First real cold weather hit us today and the thermom got dowh around 40.But guess it will soon be with us in earnest. No news but am $0, K^{\prime}$. and trying to keep so.But with the changes in temperature it is eome job.Dodgers. went down and the Cardinals won the pennant. But they won it by only two games in 154 played, for the season. Hope you are "Quite Fit" aas the englishman man said/

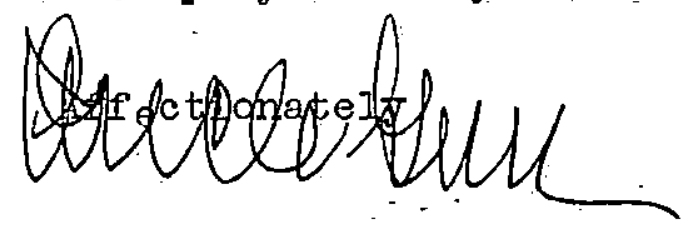

